\title{
Analisis kesalahan Ejaan Yang Disempurnakan (eyd) Dalam Proposal Skripsi Mahasiswa
}

\author{
Ummul Khair \\ Sekolah Tinggi Agama Islam Negeri Curup \\ Jalan AK. Gani No. 1, Curup, Bengkulu \\ E-mail: ummulkhair1213@gmail.com
}

\begin{abstract}
Abstrak: Tujuan penelitian teks ini adalah untuk mengetahui seberapa banyak tingkat kesalahan penulisan yang dilakukan mahasiswa dalam penggunaan bahasa tulis dalam menyusun suatu proposal skripsi. Metode yang digunakan dalam penganalisissan data penelitian teks ini adalah metode teks, yaitu mengumpulkan sejumlah teks sampel, selanjutnya membaca dan menganalisi penulisan yang dilakukan mahasiswa, dan juga menggunakan metode deskriptif analisis. Hasilnya, 1) kesalahan penulisan huruf besar (kapital) pada proposal mahasiswa STAIN Curup semester VIII tahun akademik 2012/2013 sebanyak 850 kata, dengan persentase 40,59\%; 2) kesalahan penulisan ejaan pada proposal mahasiswa STAIN Curup semester VIII tahun akademik 2012/2013 sebanyak 681 kata, dengan persentase 32, $52 \%$; 3) Kesalahan penulisan kata depan (di, ke dan dari) pada proposal mahasiswa STAIN Curup semester VIII tahun akademik 2012/2013 sebanyak 282 kata, dengan persentase 13,46\%; 3) Kesalahan penulisan tanda baca titik (.), koma (,), titik dua (:), titik koma (;), dan petik (") pada proposal mahasiswa sebanyak 281 kata, persentasenya 13,41\%.
\end{abstract}

Kata kunci: analisis EYD, proposal skripsi, mahasiswa semester VIII

\begin{abstract}
This text study objective was to determine how much the level of student writing errors made in the use of written language in developing a thesis proposal. The method used in the research data penganalisissan this text is the text method, which collects a number of text samples, further reading and doing analyzing student writing done, and also uses descriptive method of analysis. As the results, 1) error writing uppercase (capital) in the student proposal STAIN Curup VIII semester of academic year 2012/2013 as many as 850 words, with a percentage of $40.59 \%$; 2) error writing spelling on student proposals STAIN Curup VIII semester of academic year 2012/2013 as many as 681 words, with a percentage of 32, $52 \%$; 3) error writing prepositions (di, ke and dari) the student proposal STAIN Curup
\end{abstract}


ISSN 2622-1810 (p) 2622-1829 (e)

VIII semester of academic year 2012/2013 as many as 282 words, with a percentage of $13.46 \%$;) error writing punctuation dot (.), comma (.), colon (:), semicolon (;), and quotes (") on student proposals as many as 281 words, with a percentage of $13.41 \%$.

Keywords: EYD analysis, thesis proposal, student of eighth semester

\section{Pendahuluan}

Bahasa berfungsi sebagai alat komunikasi baik secara lisan maupun secara tulisan. Fungsi bahasa adalah suatu alat untuk mengungkapkan suartau suatu ide lewat pemikiran, perasaan, dan kemauan yang murni manusiawi dan tidak instingtif, dengan pertolongan sistem lambanglambang yang diciptakan dengan sengaja. (Abdul Chaer, 2002: 84) Penyampaian informasi atau pesan tersebut tentunya dengan menggunakan kalimat. Maka dari itu, agar pesan yang disampaikan oleh penutur dapat diterima oleh audien hendaknya perlu memperhatikan penyusunan kalimat efektif, dan penggunaan ejaan atau tanda baca yang benar.Ragam bahasa tulis adalah ragam bahasa yang digunakan melalui media tulis, tidak terkait ruang dan waktu sehingga diperlukan kelengkapan struktur sampai pada sasaran secara visual atau bahasa yang dihasilkan dengan memanfaatkan tulisan dengan huruf sebagai unsur dasarnya.

Pada setiap kegiatan yang dilakukan manusia dan gerak manusia sebagai makhluk yang berbudaya dan masyarakat, tidak pernah lepas dari bahasa. Tidak ada kegiatan manusia yang tidak disertai oleh bahasa. Salah satu kegiatan manusia yang setiap hari dilakukan adalah berkomunikasi. Dalam berkomunikasi, bahasa memiliki peranan penting untuk menyampaikan berita.

Untuk menyampaikan berita (pesan, amanat, ide dan pikiran) dibutuhkan bahasa yang singkat, jelas dan padat. Fungsinya adalah agar segala sesuatu yang disampaikan mudah dimengerti. Namun, dalam menggunakan bahasa tersebut pemakai bahasa tetaplah mengikuti kaidah-kaidah atau aturan yang benar karena bahasa yang benar akan dijadikan acuan atau model oleh masyarakat pemakai bahasa, dan ragam itu digunakan dalam situasi resmi. Kenyataannya sekarang banyak 
pemakai bahasa yang tidak menyadari bahwa bahasa yang digunakan tidak benar atau masih terdapat kesalahan-kesalahan.

Kesalahan-kesalahan ejaan yang banyak dilakukan dalam menuliskan bahasa Indonesia yang baik dan benar, memang merupakan kesalahan umum yang banyak terjadi, dan banyak atau pernah dilakukan oleh siapa saja diantara kita. Namun, kalau kita mengakui bahwa bahasa Indonesia adalah bahasa nasional dan bahasa negara, kita harus berusaha menggunakannya sebaik mungkin. Bagaimana orang lain bisa menghargai bahasa kita kalau kita sendiri tidak terlalu peduli kepada bahasa kita itu, termasuk dalam hal penggunaan ejaan. (Alwi Hasan, 2003: 311)

Satu tradisi dalam dunia kemahasiswaan yang tidak bisa atau bahkan sangat tidak mungkin untuk ditinggalkan oleh mahasiswa adalah menulis. Dari kegiatan ini, mahasiswa akan menghasilkan karya yang secara umum disebut tulisan. Dalam bentuk formal, tulisan itu berupa usulan kegiatan, laporan kerja/praktikum, tulisan ilmiah dalam jurnal, skripsi (khusus untuk mahasiswa strata S1).

Laporan penelitian karya ilmiah skripsi merupakan karya ilmiah yang menjadi salah satu muara akhir persyaratan menjadi seorang sarjana. Skripsi disebut dengan istilah karya ilmiah mengacu pada karya tulis yang penyusunannya didasarkan pada kajian ilmiah, berupa data-data fakta, dengan pendeskripsian data yang dipaparkan dengan penjelasan bahasa-bahasa ilmiah oleh peneliti.

Untuk dapat memaparkan suatu hasil penelitian seorang mahasiswa sekaligus peneliti, haruslah mampu menulis dalam bentuk-bentuk penggunaan ejaan yang benar, dengan berpedoman pada buku EYD dan KBBI bahasa Indonesia. Oleh karena bahasa yang tidak dikendalikan dengan teknik tata tulis laporan karya ilmiah, tata bahasa Indonesia yang benar, maupun logika berbahasa ilmiah akan mudah terinterferensi oleh bahasa daerah setempat, dialek tertentu, maupun idiolek perorangan. Dampaknya, masyarakat dari budaya daerah lain yang berbahasa Indonesia yang berasal dari Sabang sampai Merauke ini akan mengalami ambiguitas, kebiasaan, bahkan dapat menyebabkan salah tafsir. 
ISSN 2622-1810 (p) 2622-1829 (e)

Mahasiswa sebagai orang terpelajar telah mendapat kesempatan seluas-luasnya untuk menulis sekaligus mempelajari penggunaaan EYD dalam hal tulis menulis terutama dalam laporan ilmiah. Hal ini memiliki konsekuensi bahwa mereka harus mampu menggunakan bahasa baku dalam berbagai kepentingan yang bersifat resmi baik tulis maupun lisan. Dalam hal ini, untuk menghasilkan karya ilmiah yang baik seperti skripsi, mahasiswa perlu menguasai penggunaan EYD. Hal ini wajar karena tanpa mempedomani EYD gagasan dan pikiran yang akan disampaikan penulis kepada pembaca bisa salah tafsir.

Kalimat adalah satuan bahasa terkecil, dalam wujud lisan atau tulisan, yang mengungkapkan pikiran mengungkapkan pemikiran yang utuh. (Werdiningsih, 2002: 77) Selanjutnya bahwa kalimat adalah serangkaian kata yang tersusun secara bersistem sesuai dengan kaidah yang berlaku untuk mengungkapkan gagasan, pikiran, atau perasaan yang relatif lengkap. Kesatuan kalimat dalam bahasa tulis dimulai dari penggunaan huruf kapital pada awal kalimat dan diakhiri dengan pengunaan tanda titik, tanda seru atau tanda tanya pada akhir kalimat. (Wijajanti, 2006: 3)

Dari hasil observasi awal peneliti terhadap hasil membaca pada proposal skripsi mahasiswa PGMI kelas reguler ternyata kemampuan bahasa Indonesia yang dituangkan baik sebagai karya-karya tulis yang mereka susun, maupun dari jawaban-jawaban pada waktu ujian mahasiswa belum sebagaimana yang terdapat dalam pedoman ejaan yang disempurnakan (EYD). Berdasarkan temuan hasil membaca tersebut, mata kuliah bahasa Indonesia pada tingkat perguruan tinggi dipandang sangat penting ditangani secara sungguh-sungguh. Pemakaian Bahasa Indonesia pada proposal skripsi mahasiswa juga penting untuk diteliti.

Penulisan bahasa dalam skripsi mahasiswa adalah ragam bahasa baku, ragam bahasa ilmiah. Atas dasar pemikiran ini, peneliti ingin melakukan penelitian tentang bagaimana penulisan huruf kapital, huruf miring, penulisan kata depan dan penulisan tanda baca dalam proposal skripsi mahasiswa kelas reguler prodi PGMI STAIN Curup.

Bentuk penulisan bahasa berdasarkan ejaan yang disempurnakan (EYD) secara garis besar sebanyak 77 bentuk. Mengingat luasnya masalah yang berkaitan dengan kesalahan bahasa tulis, perlu adanya pembatasan 
masalahagar lebih terfokus pada inti permasalahan, dan teridentifikasi dengan jelas, maka yang diteliti dalam laporan penelitian ilmiah ini adalah proposal skripsimahasiswa kelas Reguler PGMI STAIN Curup pada semester VIII tahun akademik 2012/2013. Oleh karena itu, masalah pokok yang diajukan adalah sebagai berikut:

1. Pemakaian huruf kapital dalam penulisan proposal skripsi mahasiswa reguler semester VIII PGMI tahun akademik 2012/2013;

2. Penulisan ejaan yang disempurnakan (EYD) dalam penulisan proposal skripsi mahasiswa reguler PGMI tahun akademik 2012/2013;

3. Penulisan kata depan (di, ke, dari) dalam penulisan skripsi mahasiswa reguler PGMI tahun akademik 2012/2013;

4. Pemakaian tanda baca: ((.) (,) (:) (;)) dalam penulisan proposal skripsi mahasiswa reguler PGMI tahun akademik 2012/2013.

Sehubungan dengan batasan masalah yang telah dikemukakan, maka masalah pokok yang akan dijawab dalam penelitian yang berkaitan dengan kesalahan ejaan sebagai berikut:

1. Bagaimana pemakaian huruf kapital dalam penulisan proposal skripsi mahasiswa reguler PGMI tahun akademik 2012/2013?

2. Bagaimana penulisan ejaan dalam penulisan proposal skripsi mahasiswa reguler PGMI tahun akademik 2012/2013?

3. Bagaimana penulisan kata depan dalam penulisan proposal skripsi mahasiswa reguler PGMI tahun akademik 2012/2013?

4. Bagaimana pemakaian tanda baca dalam penulisan proposal skripsi mahasiswa reguler PGMI tahun akademik 2012/2013?

Berdasarkan rumusan masalah yang telah dikemukakan, tujuan penelitian yang ingin dicapai sebagai berikut:

1. Untuk menganalisis pemakaian huruf kapital dalam penulisan proposal skripsi mahasiswa reguler PGMI tahun akademik $2012 / 2013$

2. Untuk menganalisis ejaan dalam penulisan proposal skripsi mahasiswa reguler PGMI tahun akademik 2012/2013. 
ISSN 2622-1810 (p) 2622-1829 (e)

3. Untuk menganalisis penulisan kata depan dalam penulisan proposal skripsi mahasiswa reguler PGMI tahun akademik $2012 / 2013$

4. Untuk menganalisis penulisan tanda baca dalam proposal skripsi mahasiswa reguler PGMItahun akademik 2012/2013.

Hasil penelitian ini diharapkan berguna bagi:

1. Secara teoritis, penelitian ini memberi daya guna pengembangan disiplin ilmu-ilmu bahasa dalam penulisan yang benar berdasarkan EYD.

2. Secara praktis, penelitian berguna bagi:

a. Penelitian ini dapat memberikan masukkan kepada peneliti sebagai dosen pengampu matakuliah bahasa Indonesia, untuk lebih menerapkan pemahaman dan penggunaan EYD dalam setiap kegiatan menulis mahasiswa.

b. Penelitian ini dapat memberikan masukkan kepada peneliti untuk lebih memperhatikan penulisan EYD dalam proposal skripsi mahasiswa.

c. Penelitian ini diharapkan dapat menguak dan menyingkap kesalahan berbahasa dalam proposal penelitian ilmiah skripsi mahasiswa kelas reguler prodi PGMI STAIN Curup. Hal ini dimaksudkan untuk memberikan penjelasan tentang kenyataan hasil tulisan ilmiah mahasiswa sehingga akhirnya dapat dilakukan pembenahan dan perbaikan kedepannya.

\section{Metode Penelitian}

Penelitian ini merupakan jenis penelitian kepustakaan/library research, yakni melalui pengumpulan data atau karya tulis ilmiah yang bersifat kepustakaan dan juga termasuk jenis penelitian deskriptif kualitatif berupa analisis kesalahan dalam teks. Penelitian ini memiliki karakteristik bahwa datanya dinyatakan dalam keadaan sewajarnya atau sebagaimana adanya dengan tidak mengubah dalam bentuk simbol ataupun bilangan karena metode penelitian ini memang tidak menggunakan data statistik. (Widjajanti, 2006: 3) 
Sumber data untuk penelitian ini adalah proposal skripsi mahasiswa kelas reguler STAIN Curup STAIN Curup. Penelitian analisis teks ini peneliti laksanakan di STAIN Curup dan dilaksanakan dalam jangka waktu 3 (tiga) bulan. Penelitian ini dimulai pada bulan Juni hingga bulan Agustus.

Pengumpulan data menggunakan metode dokumentasi, yaitu suatu metode untuk mencari data variabel yang berupa catatan-catatan penting, transkip, buku, prasasti dan lain sebagainya. Pengumpulan data dalam penelitian ini yaitu proposal-proposal skripsi mahasiswa kelas reguler STAIN Curup, sebanyak 25\% persen dari jumlah mahasiswa. Instrumen yang digunakan pada penelitian analisis teks adalah dengan menggunakan pencatatan pada kartu data, selanjutnya dilakukan penghitungan dari data yang diperoleh

Analisis data dalam kajian pustaka/library research ini adalah analisis kesalahan. ${ }^{1}$ (Depdikbud, 2008: 3). Dalam hal ini analisis kesalahan yang dimaksudkan analisis kesalahan penulisan proposal penelitian (skripsi) pada tata bahasa baku ejaan yang disempurnakan Bahasa Indonesia yang baik dan benar serta dengan cara pengecekkan sumber data yang terbaca itu. (Keraf Gorys, 2003: 65)

\section{Landasan Teoritik}

1. Penjelasan Istilah

Apa yang dimaksud dengan istilah analisis? Analisis adalah penyelidikan terhadap suatu peristiwa untuk mengetahui keadaan yang sebenarnya. (Edi, 2003: 65)

Pemakaian ejaan yang benar merupakan salah satu faktor yang menentukan kesempurnaan bahasa skripsi. Ejaan untuk bahasa Indonesia adalah Ejaan Yang Disempurnakan (EYD). dengan demikian dapat dikatakan bahwa kaidah bahasa skripsi adalah EYD. Pembakuan bahasa skripsi berarti juga standarisasi penulisannya.Standarisasi penulisan menyangkut berbagai hal. Standar artinya baku, tetap, dan tidak berubah setiap saat. Ada kaidah-kaidah bahasa yang mantap.Kaidah-kaidah bahasa inilah yang menjadi tolak ukur agar bahasa 
ISSN 2622-1810 (p) 2622-1829 (e)

skripsi standar. Keseluruhan kaidah EYD tersebut dapat ditemukan dalam buku Pedomaan Ejaan Bahasa Indonesia yang Disempurnakan. (Gie, 2002: 119)

Ejaan adalah penggambaran bunyi bahasa dengan kaidah tulis menulis yang distandarisasikan, yang lazim mempunyai 3 aspek, yakni aspek fonologis yang menyangkut penggambaran fonem dengan huruf dan penyusunan abjad, aspek morfologis yang menyangkut penggambaran satuan-satuan morfemis, aspek sintaksis yang menyangkut penanda ujaran berupa tanda baca. (Pusbuk, 1988: 6)

Skripsi menurut Widodo adalah karya ilmiah yang wajib ditulis oleh mahasiswa S1 untuk memenuhi persyaratan pendidikan akademisnya. (Depdikbud, 1988: 6). Kemudian The Liang Gie menyatakan skripsi adalah suatu macam karya ilmiah yang memaparkan sebuah pokok soal yang cukup penting dalam suatu cabang ilmu sebagai hasil penelitian pustaka dan/atau lapangan yang dilakukan oleh seseorang mahasiswa berdasarkan penguasaan akademik dari perguruan tingginya untuk menjadi salah satu persyaratan kelulusannya sebagai sarjana. ${ }^{2}$ (Kridalasana, KBBI. 2008 h. 54)

\section{Ragam Bahasa Baku Indonesia}

Bahasa laporan penelitian merupakan salah satu ragam bahasa Indonesia. Ragam ini sering disebut sebagai ragam bahasa baku, ragam bahasa ilmiah, ragam bahasa standar, atau ragam bahasa ilmu. Moeliono menyatakan bahwa ragam bahasa baku memiliki tiga ciri dasar yaitu: (1) Ragam bahasa standar memiliki kemantapan dinamis, (2) Ciri kedua yang menandai bahasa baku adalah sifat kecendekiaannya, (3) Baku atau standar berpra-anggapan adanya keseragaman. Proses pembakuan sampai taraf tertentu berarti proses penyeragaman kaidah, bukan penyamaan ragam bahasa atau penyeragaman variasi bahasa. (Pusbuk. EYD. 1996. h. 13)

Dalam pemakaiannya, bahasa Indonesia ditemukan beberapa ragam bahasa. Mulai dari bahasa kehidupan sehari-hari, bahasa anak muda, bahasa lisan, bahasa tulis, dan sebagainya. Adapun ciri-ciri ragam baku 
bahasa Indonesia dapat diperikan sebagai berikut ini. Pertama, baik secara lisan maupun tulisan, ragam baku digunakan dalam situasi resmi. Ragam baku tidak diwarnai dengan dialek atau logat tertentu. Kedua, baik secara lisan maupun tulisan, ragam baku menggunakan ketentuanketentuan yang berlaku dalam Pedoman Umum Ejaan Bahasa Indonesia Yang Disempurnakan dan Pedoman Umum Pembentukan Istilah. Ketiga, baik secara lisan maupun tulisan, ragam baku memenuhi fungsi gramatikal seperti subjek, predikat, dan objek secara eksplisit dan lengkap. (Pusat Pembinaan Bahasa, 1987: 18)

a. Pedoman umum ejaan yang disempurnakan: (Wijosudarmo, 1987: 193)

1) Penulisan Huruf Kapital dalam Bahasa Indonesia.

Dalam Pedoman Umum EYD terdapat beberapa kaidah penulisan huruf kapital.Berikut ini disajikan beberapa hal yang masih perlu kita perhatikan.

- Huruf kapital dipakai sebagai huruf pertama pada awal kalimat.

Contoh: Dia mengantuk; Apa maksudnya?; dll.

- Huruf kapital dipakai sebagai huruf pertama petikan langsung.

Contoh: Adik bertanya:"Kapan kita pulang?"

- Huruf kapital dipakai sebagai huruf pertama dalam menulis ungkapan yang berhubungan dengan hal keagamaan, kitab suci, dan nama Tuhan, termasuk kata ganti untuk Tuhan.

Contoh: Allah, Yang Mahakuasa, Atasrahmat-Mu (bukan atas rahmatmu), dll.

- Huruf kapital tidak dipakai sebagai huruf pertama untuk menuliskan kata-kata, seperti, imam, makmum, doa, puasa, dan misa.

- Huruf kapital dipakai sebagai huruf pertamagelar kehormatan, keturunan dan keagamaan yang diikuti nama orang.

Contoh: Sultan Hasanuddin, Nabi Muhammad, Imam Hanafi, dll. 


\section{2) Penulisan Kata yang Benar Menurut EYD}

Kata dasar ditulis sebagai satu kesatuan. Contoh: Ibu percaya bahwa engkau tahu.

- Imbuhan (awalan, sisipan, akhiran) ditulis serangkai dengan kata dasar. Contoh: bergeletar, dikelola

- Jika kata dasar berbentuk gabungan kata, awalan atau akhiran ditulis serangkai dengan kata yang langsung mengikuti atau mendahuluinya. Tanda hubung boleh digunakan untuk memperjelas. Contoh: bertepuk tangan, garis bawahi

- Jika kata dasar berbentuk gabungan kata mendapat awalan dan akhiran sekaligus, unsur gabungan ditulis serangkai. Tanda hubung boleh digunakan untuk memperjelas. Contoh: menggarisbawahi, dilipatgandakan.

- Jika salah satu unsur gabungan hanya dipakai dalam kombinasi, gabungan kata ditulis serangkai. Contoh: adipati, mancanegara.

- Jika kata dasar huruf awalnya adalah huruf kapital, diselipkan tanda hubung. Contoh: non-Indonesia.

- Bentuk ulang ditulis secara lengkap dengan menggunakan tanda hubung, baik yang berarti tunggal (lumba-lumba, kupukupu), jamak (anak-anak, buku-buku) maupun yang berbentuk berubah beraturan (sayur-mayur, ramah-tamah)

- Gabungan kata atau kata majemuk

3) Penulisan Kata Depan (preposisi) (Ronny Kountur, 2004: 24)

Kata depan di, ke, dan dari ditulis terpisah dari kata yang mengikutinya. Contoh: di rumah; di sini; di mana; di samping; ke mana; ke sana; ke muka; dari mana; dari rumah; dll.

Tetapi, perhatikan awalan di-dan $k e$-ditulis serangkai dengan kata yang mengikutinya. Contoh: disampaikan; dibaca; dikemukakan; ketujuh; keputusan; kekasih; dll.

4) Tanda Titik (.)

Tanda titik dipakai pada akhir kalimat yang bukan pertanyaan atau seruan. Contoh: Saya suka makan nasi. Apabila dilanjutkan dengan kalimat baru, harus diberi jarak satu ketukan. 
Tanda titik dipakai pada akhir singkatan nama orang. Contoh:

- Irwan S. Gatot

- George W. Bush

Apabila nama itu ditulis lengkap, tanda titik tidak dipergunakan. Contoh: Dwiki Halla

Tanda titik dipakai pada akhir singkatan gelar, jabatan, pangkat, dan sapaan. Contoh:

- Dr. (doktor)

- S.E. (sarjana ekonomi)

- Kol. (kolonel)

- Bpk. (bapak)

Tanda titik dipakai pada singkatan kata atau ungkapan yang sudah sangat umum.Pada singkatan yang terdiri atas tiga huruf atau lebih hanya dipakai satu tanda titik. Contoh:

- dll. (dan lain-lain)

- dsb. (dan sebagainya)

- tgl. (tanggal)

- hlm. (halaman)

Tanda titik dipakai untuk memisahkan angka jam, menit, dan detik yang menunjukkan waktu atau jangka waktu.Contoh:

- Pukul 7.10.12 (pukul 7 lewat 10 menit 12 detik)

- $\quad 0.20 .30$ jam (20 menit, 30 detik)

Tanda titik dipakai untuk memisahkan bilangan ribuan atau kelipatannya.

Contoh: Kota kecil itu berpenduduk 51.156 orang.

Tanda titik tidak dipakai untuk memisahkan bilangan ribuan atau kelipatannya yang tidak menunjukkan jumlah. Contoh:

- Nama Ivan terdapat pada halaman 1210 dan dicetak tebal.

- Nomor Giro 033983 telah saya berikan kepada Mamat.

5) Tanda Koma (,)

Tanda koma dipakai di antara unsur-unsur dalam suatu pemerincian atau pembilangan. Contoh: Saya menjual baju, celana, dan topi. Contoh penggunaan yang salah: Saya membeli udang, kepiting dan ikan. 
ISSN 2622-1810 (p) 2622-1829 (e)

Tanda koma dipakai untuk memisahkan kalimat setara yang satu dari kalimat setara yang berikutnya, yang didahului oleh kata seperti, tetapi, dan melainkan. Contoh: Saya bergabung dengan Wikipedia, tetapi tidak aktif.

Tanda koma dipakai untuk memisahkan anak kalimat dari induk kalimat apabila anak kalimat tersebut mendahului induk kalimatnya. Contoh:

- Kalau hari hujan, saya tidak akan datang.

- Karena sibuk, ia lupa akan janjinya.

Tanda koma tidak dipakai untuk memisahkan anak kalimat dari induk kalimat apabila anak kalimat tersebut mengiringi induk kalimat. Contoh: Saya tidak akan datang kalau hari hujan.

Tanda koma dipakai di belakang kata atau ungkapan penghubung antara kalimat yang terdapat pada awal kalimat. Termasuk di dalamnya oleh karena itu, jadi, lagi pula, meskipun begitu,akan tetapi. Contoh

- Oleh karena itu, kamu harus datang.

- Jadi, saya tidak jadi datang.

Tanda koma dipakai di belakang kata-kata seperti o, ya, wah, aduh, kasihan, yang terdapat pada awal kalimat.contoh:

- 0 , begitu.

- Wah, bukan main.

Tanda koma dipakai untuk memisahkan petikan langsung dari bagian lain dalam kalimat. Contoh: Kata adik, "Saya sedih sekali".

6) Tanda Titik Koma (;)

Tanda titik koma dapat dipakai untuk memisahkan bagian-bagian kalimat yang sejenis dan setara. Contoh: Malam makin larut; kami belum selesai juga.

Tanda titik koma dapat dipakai untuk memisahkan kalimat yang setara di dalam suatu kalimat majemuk sebagai pengganti kata penghubung. Contoh: Ayah mengurus tanamannya di kebun; ibu sibuk bekerja di dapur; adik menghafalkan nama-nama pahlawan nasional; saya sendiri asyik mendengarkan siaran pilihan pendengar.

7) Tanda Titik Dua (:) 
Tanda titik dua dipakai pada akhir suatu pernyataan lengkap bila diikuti rangkaian atau pemerian.Contoh:

- Kita sekarang memerlukan perabotan rumah tangga: kursi, meja, dan lemari.

- Fakultas itu mempunyai dua jurusan: Ekonomi Umum dan Ekonomi Perusahaan.

Tanda titik dua dipakai sesudah kata atau ungkapan yang memerlukan pemerian 'pemeran'. Contoh:

$\begin{array}{ll}\text { Ketua } & \text { : Axel } \\ \text { WakilKetua } & \text { : Putri } \\ \text { Sekretaris } & \text { : Helena }\end{array}$

Tanda titik dua dipakai dalam teks drama sesudah kata yang menunjukkan pelaku dalam percakapan. Contoh:

Borgx : "Jangan lupa perbaiki halaman bantuan Wikipedia!"

Rex : "Siap, Boss!"

Tanda titik dua dipakai (i) di antara jilid atau nomor dan halaman, (ii) di antara bab dan ayat dalam kitab-kitab suci, atau (iii) di antara judul dan anak judul suatu karangan. Contoh:

- Tempo, I (1971), 34: 7

- Surah Yasin:9

- Karangan Ali Hakim, Pendidikan Seumur Hidup: Sebuah Studi, sudah terbit.

Tanda titik dua dipakai untuk menandakan nisbah (angka banding). Contoh: Nisbah siswa laki-laki terhadap perempuan ialah 2 : 1 .

Tanda titik dua tidak dipakai kalau rangkaian atau pemerian itu merupakan pelengkap yang mengakhiri pernyataan. Contoh: Kita memerlukan kursi, meja, dan lemari.

\section{Hasil Temuan dan Pembahasan}

Setelah peneliti melakukan beberapa tahap dalam penelitian analisis teks ini, pertama mengumpulkan sampel proposal, selanjutnya membaca, dilanjutkan dengan menandai unsur-unsur kesalahan, mencatat dalam tabel dan terakhir menghitung jumlah dan presentase kesalahan, maka 
44 | ESTETIK, Vol. 1 No. 1, Juni 2018

ISSN 2622-1810 (p) 2622-1829 (e)

didapatlah hasil temuan penelitian sebagai berikut, dilanjutkan dengan deskripsinya dengan analisis isi.

Temuan data hasil penelitian analisis teks proposal mahasiswa kelas reguler PGMI STAIN Curup dapat dilihat dalam tabel berikut:

Tabel Hasil Analisis

Kesalahan Penulisan Bahasa dalam Proposal

\begin{tabular}{|c|c|c|}
\hline Jenis Kesaahan & $\begin{array}{c}\text { Jumlah } \\
\text { kesalahan }\end{array}$ & $\begin{array}{c}\text { Presentase } \\
\text { \% }\end{array}$ \\
\hline 1. Kesalahan penulisan huruf kapital & 850 & $40,59 \%$ \\
\hline 2. Kesalahn penulisan ejaan & 681 & $32,52 \%$ \\
\hline $\begin{array}{l}\text { 3. Kesalahn penulisan preposisi: di, } \\
\text { ke, darai dan di }\end{array}$ & 282 & $13,46 \%$ \\
\hline $\begin{array}{l}\text { 4. Kesalahan penulisan tanda baca: } \\
\text { a. titik (.) }\end{array}$ & 145 & \\
b. koma (,) & 65 & $13,41 \%$ \\
c. titik dua (:) & 46 & $99.98 \%$ \\
d. titik koma (;) \\
e. tanda petik dua (")
\end{tabular}

Penulisan huruf besar (kapital) 
Penulisan huruf besar atau yang disebut dalam istilah ketatabahasaan sebagai huruf kapital.Banyak makna dan fungsi yang ditimbulkan apabila penulisan huruf capital salah dalam penggunaannya.

Huruf besar atau yang disebut juga dengan istilah kebahasaan sebagai huruf kapital.Berdasarkan buku ejaan yang disempurnakan, terdapat 15 bentuk atau ketentuan dalam penggunaan huruf kapital dalam penulisan bahasa Indonesia.

Berdasarkan analisis data pada kategori penulisan huruf kapital yang terdapat pada sampel yang diambil berdasarkan analisis teks proposal skripsi mahasiswa terdapat tingkat kesalahan penulisan kata yang paling tinggi frekuensinya sebanyak 850 bentuk kesalahan dengan jumlah persentase kesalahan 40,59\% dari 32 sampel proposal.

Hal ini menunjukkan bahwa dalam penulisan proposal skripsi khususnya mahasiswa PGMI semester VIII penulisan hurup besar (kapital) masuk dalam kategori yang terbanyak terdapat kesalahan. Adapun kesalahan penulisan huruf besar (kapital) banyak terdapat pada awal kalimat, nama tempat, nama orang, nama bulan serta dalam penulisan pengarang buku. (kategori nama orang), tempat terbit, dan penerbit.

Contoh kesalahan penulisan huruf besar (kapital) pada hal-hal tersebut sebagai berikut (Abdul Halim, 2011: 274):

Tabel

Contoh Penulisan Huruf Kapital yang Peneliti Temukan

\begin{tabular}{|c|l|l|}
\hline No & \multicolumn{1}{|c|}{ Penulisan yang salah } & \multicolumn{1}{|c|}{ Penulisan sesuai EYD } \\
\hline 1. & meningkatakan & Meningkatkan \\
\hline 2. & Taringan & Taringan \\
\hline 3. & Oktober & Oktober \\
\hline 4. & Jakarta & Jakarta \\
\hline
\end{tabular}


46 | ESTETIK, Vol. 1 No. 1, Juni 2018

ISSN 2622-1810 (p) 2622-1829 (e)

\begin{tabular}{|c|l|l|}
\hline 5. & Syaful bahri djamarah & Syaiful Bahri Djamarah \\
\hline 6. & Pt raja grafindo & PT. Raja Grafindo \\
\hline
\end{tabular}

Dari beberapa contoh kesalahan penulisan huruf besar (kapital) di atas menunjukkan bahwa pada penulisan karya ilmiah yang dalam hal ini proposal penelitian mahasiswa STAIN Curup masih banyak kesalahan pada hal-hal yang seharusnya menjadi pedoman/perhatian khusus dalam tata bahasa penulisan sebuah karya ilmiah yang baik dan benar.

Sebagaimana dalam buku, Pedoman Umum Ejaan Bahasa Indonesia Yang Disempurnakan, untuk penulisan huruf kapital atau huruf besar dengan ketentuan sebagai berikut (Lexy J, 2004: 178):

1. Huruf kapital atau huruf besar dipakai sebagai huruf pertama kata pada awal kalimat. Contoh : Pekerjaan itu belum selesai.

2. Huruf kapital dipakai sebagai huruf pertama unsur-unsur nama orang. Contoh: Amir Hamzah

3. Huruf kapital dipakai sebagai huruf pertama nama tahun, bulan, hari, hari raya, dan peristiwa sejarah. Contoh: bulan Agustus, hari Jumat, tahun Hijriah dsb.

Penulisan ejaan yang disempurnakan (EYD)

Penulisan ejaan atau yang disebut juga penulisan yang benar berdasarkan pedoman umum ejaan yang disempurnakan (EYD). Kata yang terdiri dari susunan huruf yang mempunyai makna, setiap susunan huruf dalam bahasa tentu akan menghasilkan bunyi yang berbeda, dari bunyi yang berbeda tentu akan menghasilkan makna yang berbeda juga. Penelitian analisis teks ini menemukan sebanyak kesalahan 681 bentuk kesalahan penulisan ejaan dalam sampel skripsi mahasiswa dengan jumlah persentasae kesalahan $32,52 \%$, misalnya:

- tersusu dengan tersusun

- unyuk dengan untuk

- hinggs dengan hingga, dll

Apabiladitelaah makna yang ditimbulkan oleh kesalahan penulisan ejaan yang digunakan salah seorang mahasiswa PGMI kelas reguler dalam 
suatu laporan maka akan menghasilkan makna yang berbeda. Makna kata tersusu adalah menysui seorang anak dengan tidak sengaja, padahal makan dan kata yang akan dituliskan oleh seorang penulis skripsi adalah, kata tersusun dengan makna kata, susunan sesuatu hal. Begitu juga dengan kata kedua, unyuk dengan untuk, kata unyuk adalah bahasa prokem yang kadang digunakan oleh para remaja, yang mereka maknai dengan mengemeskan, sedangkan makna sebenarnya yang dimaksud adalah kata untuk, yang bermakna tertuju, atau menyatakan peruntukkan.Jadi betapa besarnya kekeliruan makna yang ditimbulkan oleh suatau kesalahan penulisan kata dalam suatu keterampilan menulis mahasiswa, khusunya dalam proposal skripsi.

Dalam penulisan ejaan bahasa Indonesia, berdasarkan ejaan yang disempurnakan terdapat 7 kategori ejaan dalam peristilahan. Pada analisis teks ini ejaan yang peneliti maksudkan adalah penulisan/ penggunaan ejaan secara umum.

Berdasarkan analisis teks proposal mahasiswa yang menjadi sampel penelitian pada kesalahan penulisan ejaan berjumlah681 kata dengan urutan kedua frekuensi kesalahan 32,52\%. Kesalahan-kesalahan ini ditemui pada proposal skripsi mahasiswa STAIN Curup semester VIII tahun akademik 2012/2013, termasuk dalam kategori banyak. Adapun kesalahan ejaan yang ditemukan banyak terdapat pada kurangnya huruf dalam kata, penulisan huruf yang salah dalam satu kata, penggabungan dua atau tiga kata yang seharusnya dipisah dan juga penulisan ejaan yang salah pada akhir huruf. Contoh penulisan ejaan yang peneliti temukan sebagai berikut:

Tabel

Contoh Penulisan Ejaan Yang Peneliti Temukan

\begin{tabular}{|l|l|}
\hline \multicolumn{1}{|c|}{$\begin{array}{c}\text { Penulisan ejaan yang tidak } \\
\text { mengikuti pedoman EYD }\end{array}$} & Penulisan ejaan yang sesuai EYD \\
\hline Pengetauan & pengetahuan \\
\hline Cendrung & cenderung \\
\hline Defenisi & definisi \\
\hline
\end{tabular}


48 | ESTETIK, Vol. 1 No. 1, Juni 2018

ISSN 2622-1810 (p) 2622-1829 (e)

\begin{tabular}{|l|l|}
\hline Propesional & profesioanal \\
\hline kesangupan seseorang & kesanggupan seseorang \\
\hline hanya bisa di lakukan & hanya bisa dilakukan \\
\hline Alternative & alternatif \\
\hline
\end{tabular}

Dari beberapa contoh di atas dan juga dari jumlah kesalahan penulisan setiap kata sangat jelas bahwa dalam menulis ejaan dalam karya ilmiah mahasiswa kurang diperhatikan, namun dalam hal ini peneliti berpendapat bahwa kesalahan ejaan ini banyak disebabkan oleh faktor ketidak sengajaan dan juga kurang cermatnya dalam membaca setiap kata pada tahap pengeditan tulisan proposal mahasiswa tersebut.

Terlepas dari pendapat peneliti, pada penulisan proposal skripsi yang merupakan salah satu kategori dari karya ilmiah, sudah seharusnya para peneliti (mahasiswa) memperhatikan ejaan yang benar dalam pedoman umum ejaan bahasa Indonesia yang disempurnakan dan berpedoman pada buku,Tata Bahasa Indonesia.

\section{Penulisan kata depan (preposisi)}

Penulisan kata depan yang ditemui pada penulisan bahasa proposal mahasiswa yang disebut dengan istilah kebahasaan preposisi. Kesalahan penulisan preposisi terdapat sebanyak 282 dengan tingkat persentase kesalahan 13, $46 \%$ bentuk kesalahan, kesalahan terjadi dari bentuk pengabungan kata depan dengan kata yang mengikutinya dan sebaliknya terpisah darai kata yang menggikutinya. Penulisan kata depan di, ke, dari menurut pedoman ejaan yang disempurnakan adalah dipisah, apabila kata tersebut menyatakan tempat. Penulisan kata depan digabung apabila suatu kata tersebut tidak menyatakan tempat.

Penulisan kata dalam bahasa Indonesia terbagi dalam 10 bentuk atau ketentuan. Adapun penulisan kata yang peneliti maksudkan pada penelitaian teks ini adalah penulisan kata depan.

Berdasarkan hasil analisis data yang peneliti temukan pada sampel penelitian, terdapat kesalahan penulisan kata depan ( $d i, k e$, dari) sebanyak 282 kata depan, dengan urutan ketiga dengan frekuensi 
kesalahan 13,46\%, pada proposal mahasiswa STAIN Curup semester VIII tahun akademik 2012/2013 dan dengan jumlah tersebut termasuk dalam kategori banyak. Adapun kata depan yang banyak kesalahan dalam penggunaannya adalah kata depan "di" dalam kalimat. Penggunaan kata depan " $d i$ " dalam kalimat ada dua macam yaitu kata depan "di" untuk menunjukkan tempat, yang harus dituliskan terpisah dari kata yang menunjukkan tempat. Kemudian kata depan "di" untuk merupakan sebuah awalan untuk sebuah kata kerja pasif, yang harus digabungkan pada kata yang diawalinya.

Penulisan kata depan dipisah dari kata yang diikutinya apabila kata yang diikutinya atau kata dodepannya menyatakan tempat. Kemudian selain kata depan "di" ada juga kata depan "ke", dan dari yang pada pedoman seharusnya ditulis terpisah dari kata yang mengikutinya kecuali di dalam gabungan kata yang sudah lazim dianggap sebagai satu kata seperti "kepada" dan "daripada". (Pusat Pembinan Bahasa, 2000: 14)

Berdasarkan contoh pedoman penggunaan kata depan di, ke dan dari di atas, dapat dijadikan acuan dalam menganalisis kesalahan penulisan kata depan dalam proposal mahasiswa sebagai berikut ini:

Banyaknya terdapat kesalahan penulisan huruf kapital sebagai contoh kesalahan penulisan huruf besar (kapital) pada hal-hal tersebut sebagai berikut:

Tabel

Contoh Penulisan Konjungsi yang Peneliti Temukan

\begin{tabular}{|l|l|}
\hline $\begin{array}{c}\text { Penggunaan konjungi di, ke, } \\
\text { dari yang tidak mengikuti } \\
\text { pedoman EYD }\end{array}$ & $\begin{array}{c}\text { Penggunaan konjungsi di, ke dan } \\
\text { dari yang mengikuti pedoman } \\
\text { EYD }\end{array}$ \\
\hline Diatas & Di atas \\
\hline Dikelas & di kelas \\
\hline daripada & Daripada \\
\hline Kejenjang & ke jenjang \\
\hline
\end{tabular}


ISSN 2622-1810 (p) 2622-1829 (e)

Jika dilihat dalam tabel di atas, sangatlah jelas bahwa dalam penulisan kata depan (di, ke dan dari) mahasiswa kurang memperhatikan penggunaan kata depan yang seharusnya digabung dan terpisah. Hal ini disebabkan karena sebelum menulis proposal mahasiswa kurang mempersiapkan diri dengan berbagai referensi yang dibutuhkan dalam hubungannya dengan keterampilan menulis. Faktor ketidaktelitihan atau tidak melakukan pengeditan dengan cermat. Pada faktor penguasaan terhadap teknik penulisan yang seharusnya yaitu pedoman EYD.

Karena sesuai dengan teorinya ejaan yang benar merupakan penggambaran bunyi bahasa (kata, kalimat, dsb) dengan kaidah tulisan (huruf) yang distandarisasikan dan mempunyai makna. Dari hal itu sangat jelas bahwa jika ada kelasahan dalam penulisan kata perkata misalnya kurang huruf atau salah huruf dalam setiap kata dalam tulisan karya ilmiah akan menggambarkan makna yang berbeda bahkan salah dan pada akhirnya akan mengakibatkan pemahaman yang salah pula, dan akhirnya tidak tercapainya tujuan penulisan yang ingin dicapai oleh seorang penulis.

\section{Penulisan tanda baca}

Kesalahan tanda baca dalam proposal mahasiswa yang dimaksud meliputi tanda baca (.), koma (,), titik dua (:), titik koma (;) dan tanda baca petik ("). Kesalahan penulisan kelima tanda baca tersebut terdapat sebanyak 281 dengan tingkat persentase 13,41\%.

Dalam pedoman penulisan ejaan yang disempurnakan, pada penulisan bahasa Indonesia, terdapat 15 pemakaian tanda baca, pada penelitian ini peneliti mempokuskan pada penulisan terhadap penggunaan tanda baca secara umum.

Ketidaktepatan penulisan tanda baca: titik (.), koma (,) titik dua (:) titik koma (;), tanda petik dua ("). Peneliti menemukan sampel penelitian sebanyak 281 kesalahan, merupakan tingkaturutan keempat dengan frekuensi 13,41 \%, pada proposal mahasiswa STAIN Curup Prodi PGMI semester VIII tahun akademik 2012/2013, dan termasuk dalam kategori sedang. Adapun kesalahan terbanyak yang ditemui adalah pada penggunaan tanda baca titik (.) umumya penggunaan pada akhir kalimat, 
sebuah kalimat harus diakhiri oleh tanda titik, seperti untuk menyatakan satu kalimat yang bukan pertanyaan atau seruan.

Selanjutnya kesalahan tanda baca koma (,), titik koma(;), titik dua (:) dan tanda baca petik (") ditemukan juga pada proposal mahasiswa sebagaimana tercantum pada tabel kesalahan penulisan tanda baca. Dan kesalahan penggunaan keempat tanda baca tersebut tidak terlalu banyak, namun akan mempengaruhi kaidah tata bahasa yang seharusnya digunakan/diterapkan dalam penulisan karya ilmiah. Misalnya pada penggunaan tanda baca koma (,) yang pada pedoman EYD disebutkan salah satunya dipakai di antara bagian-bagian dalam catatan kaki, contoh:

W. J. S. Poerwadarminta, Bahasa Indonesia untuk Karang-mengarang (Yogyakarta: UP Indonesia. 1967), h 4.

Sedangkan kesalahan yang ditemukan dalam catatan kaki penggunaan tanda baca koma (,) tidak tepat misalnya setelah penulisan tahun 2005). menggunakan tanda titik, sedangkan yang seharusnya tanda koma (,), dan begitu juga setelah (hlm,) menggunakan tanda koma, yang seharusnya menggunakan tanda baca titik (.).

\section{Simpulan}

Berdasarkan hasil penelitian yang peneliti lakukan sebagaimana telah diuraikan dalam bab empat dan lima sebelumnya, maka dapat disimpulkan sebagai berikut:

- Kesalahan penulisan huruf besar (kapital) pada proposal mahasiswa STAIN Curup semester VIII tahun akademik 2012/2013 sebanyak 850 kata, dengan persentase sebesar 40,59\%, dan jumlah tersebut termasuk dalam frekuensi urutan pertama atau yang tertinggi.

- Kesalahan penulisan ejaan pada proposal mahasiswa STAIN Curup semester VIII tahun akademik 2012/2013 sebanyak 681 kata, dengan persentase sebesar 32, $52 \%$, dan termasuk dalam frekuensi urutan kedua terbanyak.

- Kesalahan penulisan kata depan (di, ke dan dari) pada proposal mahasiswa STAIN Curup semester VIII tahun akademik 2012/2013 sebanyak 282 kata, dengan persentase sebesar 
ISSN 2622-1810 (p) 2622-1829 (e)

13,46\%, dan jumlah tersebut termasuk dalam frekuensi urutan ketiga terbanyak.

- Kesalahan penulisan tanda baca titik (.), koma (,), titik dua (:), titik koma (;), dan petik (") pada proposal mahasiswa STAIN Curup semester VIII tahun akademik 2012/2013 sebanyak 281 kata, dengan persentase sebesar $13,41 \%$, dan jumlah tersebut termasuk dalam frekuensi urutan keempat terbanyak.

Berdasarkan hasil penelitian dari sumber data yang peneliti temukan sesuai dengan judul "Analisis Kesalahan Ejaan Yang Disempurnakan (EYD) dalamProposal Skripsi Mahasiswa Reguler PGMI STAIN Curup Semester VIII, maka peneliti menyarankan kepada pihak-pihak terkait beberapa hal sebagai berikut:

1. Saran berkaitan dengan analisis selanjutnya, berdasarkan pada hasil analisis penelitian ini dapat digunakan oleh peneliti lainnya sebagai bahan acuan dan pertimbangan untuk melakukan suatu penelitian lebih lanjut dan lebih banyak lagi pada karya-karya ilmiah lainnya.

2. Saran yang berkaitan dengan mahasiswa, berdasaran hasil analisis penelitian ini dapat memberi kontribusi agar penggunakan EYD sebagai pedoman dalam menulis ilmiah (dalam hal ini proposal skripsi), harus dijadikan suatu referensi penting, sehingga tulisan karya ilmiah yang dihasilkan akan bermutu tinggi.

3. Saran yang sangat berkaitan dengan peneliti selaku dosen bahasa Indonesia, harus memperhatikan penggunaan ejaan yang disempurnakan, dalam kegiatan keterampilan berbahasa mahasiswa, terutama pada kegiatan menulis dan khusunya pada kegiatan mahasiswa dalam menulis ilmiah.

\section{Sumber Rujukan}

Abdul Chaer, Linguistik Umum. Jakarta: Rineka Cipta, 2002

Abdul Halim Hanafi, Metodologi Penelitian Bahasa untuk Penelitian, Tesis, \& Disertasi, Jakarta: Diadit Media Press, 2011 
Alwi, Hasan et all,Tata Bahasa Baku Bahasa Indonesia, Jakarta: Balai Pustaka, 2003

Departemen Pendidikan Nasioal Republik Indonesia, Kamus Besar Bahasa Indonesia. Jakarta: 2008

Depdikbud, Tata bahasa Baku Bahasa Indonesia, (Jakarata: Balai Pustaka. 1988)

Gie, The Liang, Terampil Mengarang, Yogyakarta: Andi Offset, 2002

Keraf, Gorys. Sebuah Pengantar Kemahiran Bahasa. Ende: Nusa Indah. 1993

Lexi J Moleong, Metodologi Penelitian Kulaitatif, Bandung: Remaja Karya, 2004

Mungin Edi Wibowo, Buku Penuntun Membuat Thesis dan Skripsi, Jakarta: 2003

Prastyaningsih, Luluk, Ilmu Bahasa (Linguistik), Malang: FKIP Unisma, 2001

Pusat Perbukuan Departemen Pendidikan Nasional, Tata Bahasa, Jakarta: 1988

Pusat Pembinaan dan Pengembangan Bahasa Departeman Pendidikan dan Kebudayaan Republik Indonesia, Pedoman Umum Ejaan Bahasa Indonsia yang Disempurnakan \& Pedoman Umum Pembentukan Istilah, Bandung: Pustaka Setia, 1996

Pusat Pembinaan dan Pengembangan Bahasa, Depdikbud. Pedoman Umum Ejaan Bahasa Indonesia Yang Disempurnakan. Bandung : Pustaka Setia,1987

Ronny Kountur, Metode Penelitian untuk Penulisan Skripsi dan Tesis (Jakarta: PPM, 2004)

Wirjosoedarmo, Soekono, Tata Bahasa bahasa Indonesia. Untuk SMA_Universitas Pegangan Guru. Surabaya: Sinar Wijaya, 1987

Werdiningsih, Dyah, Menulis I. Malang: FKIP Unisma, 2002

Widjajanti, Sri. Kesalahan dan Penggunaan Kalimat pada Skripsi Mahasiswa Jurusan Non-Bahasa dan Sastra Indonesia Universitas Madura, Malang: Pascasarjana (Tesis), 2006) 
54 | ESTETIK, Vol. 1 No. 1, Juni 2018

ISSN 2622-1810 (p) 2622-1829 (e) 